\title{
Upaya Peningkatan Kualitas Sifat Mekanik Komposit Polyester Dengan Serat Bundung (Scirpus Grossus) \\ Erwin ${ }^{*}$, Leo Dedy Anjiu ${ }^{\mathrm{a}}$
}

\author{
aJurusan Teknik Mesin, Politeknik Negeri Sambas \\ Jalan Raya Sejangkung, Sambas, Indonesia \\ *Email : erwin_poltesa@yahoo.com
}

\begin{abstract}
Abstrak
Tujuan penelitian komposit adalah memperkuat serat Bundung (Scirpus Grossus) untuk mengetahui sifat mekanik komposit terhadap kekuatan tarik. Metode yang dilakukan pada serat Bundung diberi perlakuan dengan perendaman 5\% NaOH selama 2 jam, kemudian dipanaskan dengan temperatur $70^{\circ} \mathrm{C}$ selama 4 jam. Penyusunan serat Bundung dengan gabungan orientasi sudut $0^{\circ}$ dan $90^{\circ}$ dengan resin polyester type 157 BTQN dengan variasi fraksi volume serat $20 \%$, $30 \%$, dan $40 \%$. Hardener yang digunakan adalah MEKPO berkonsentrasi 1\%. Komposit dibuat dengan metode hand lay up. Spesimen dan prosedur pengujian tarik mengacu pada standart ASTM D638-03. Hasil penelitian ini menunjukkan terjadi peningkatan kekuatan tarik pada penambahan fraksi volume sebesar $40 \%$ serat dengan perlakuan perendaman $5 \% \mathrm{NaOH}$ selama 2 jam dengan pemanasan $70^{\circ} \mathrm{C}$ selama 4 jam. Kekuatan tarik tertinggi komposit serat bundung pada perlakuan perendaman $5 \% \mathrm{NaOH}$ selama 2 jam dengan pemanasan $70^{\circ} \mathrm{C}$ selama 4 jam sebesar $67,56 \mathrm{~N} / \mathrm{mm}^{2}$ dibandingkan dengan kekuatan tarik pada perlakuan perendaman $5 \%$ $\mathrm{NaOH}$ selama 2 jam tanpa pemanasan yaitu sebesar $54,25 \mathrm{~N} / \mathrm{mm}^{2}$.
\end{abstract}

Kata Kunci : Bundung, Komposit, NaOH, Kekuatan Tarik.

\section{Latar Belakang}

Penggunaan material komposit dengan filler serat alam mulai banyak dikenal dalam industri manufaktur. Material yang ramah lingkungan, mampu didaur ulang, serta mampu dihancurkan sendiri oleh alam merupakan tuntutan teknologi sekarang ini. Salah satu material diharapkan mampu memenuhi hal tersebut adalah material komposit dengan material pengisi (filler) serat alam. Keunggulan yang dimiliki oleh serat alam adalah berpotensi sebagai penguat komposit, dapat diperbaharui (reneweble), ringan, murah, ramah lingkungan, dapat terbiodegradasi, tidak beracun, non-abrasif, sifat mekanik tinggi, berlimpah di Indonesia. Serat alam dapat menjadi filler dalam komposit karena kandungan selulosa. Beberapa serat alam yang memiliki selulosa antara lain kenaf, tebu, jagung, abaca, padi, ramie dan lain-lain.

Dalam penelitian ini menggunakan filler serat Bundung, Jenis pengikat yang digunakan adalah resin polyester. Resin polyester merupakan salah satu resin termoset yang mudah diperoleh dan digunakan masyarakat umum maupun industri skala kecil maupun besar. Resin polyester ini juga mempunyai kemampuan berikatan dengan serat alam tanpa menimbulkan reaksi dan gas.

Sebelum dibuat komposit, terlebih dahulu dilakukan perlakuan terhadap serat. Hal ini dimaksudkan untuk meningkatkan sifat adhesif. Adhesif adalah kelekatan permukaan dari unsurunsur yang dicampur atau disatukan. Salah satu cara untuk meningkatkan kemampuan adhesif serat adalah perlakuan Alkali (perendaman dengan $\mathrm{NaOH}$ ).

Komposit sebenarnya telah dikenal sejak dulu, tetapi baru tahun 1960-an mendapatkan perhatian dari dunia industri. Komposit merupakan bahan yang dihasilkan dari penggabungan dua atau lebih bahan dasar yang disusun secara makroskopis (Gibson, 1994). Para industriawan mulai tertarik akan penggunaan komposit sebagai produk unggulan sesuai dengan keistimewaannya, seperti ringan, kuat, tidak terpengaruh korosi, dan mampu bersaing dengan logam. Perkembangan plastik pun mulai meningkat sejak ditemukannya komposit yang secara harfiah disebut reinforced plaslic. Komposit begitu cepat diserap dan dipakai oleh industri otomotif, militer, olah raga, kedokteran, bahkan sampai peralatan rumah tangga. Produsen mobil Daimler-Chrysler AG mengembangkan komposit serat alam sebagai interior mobil (Schuh, 1996).

Delni Sriwita (2014) penelitian tentang pembuatan dan karakterisasi sifat mekanik bahan komposit seratdaun nenas-polyester ditinjau dari fraksi massa dan orientasi serat. Penelitian ini bertujuan untuk mengetahui 
pengaruh penambahan massa serat terhadap sifat mekanik pada komposit resin polyesterkhususnya kuat tarik dan kuat tekan. Resin polyester-MEKPO (Methyl Ethyl Ketone Peroxide) berperan sebagai matriks pada komposit dan serat daun nenas berperan sebagai filler pada matriks polimer resin polyester. Karakterisasi kuat tarik dan kuat tekan komposit terhadap penambahan seratdaun nenas dilakukan dengan alat uji wekob 32559 (Cesare Galdabini). Secara umum, sifat mekanikresin polyester-serat daun nenas meningkat berdasarkan penambahan serat. Nilai kuat tarik dan kuat tekan untuk komposit dengan orientasi serat searah lebih tinggi daripada orientasi serat acak. Nilai kuat tarik maksimum diperoleh pada komposit dengan penambahan serat $0,2 \mathrm{~g}$ sebesar 723,36 N/cm2 dan nilai kuat tekan pada komposit dengan penambahan serat $1,5 \mathrm{~g}$ sebesar 1768,13 N/cm2.

\section{Metodologi}

Penelitian ini dilakukan di laboratorium material Jurusan Teknik Mesin Universitas Brawijaya Malang dan Politeknik Kediri menggunakan metode eksperimental dan hand lay up dalam pembuatan komposit dengan uji tarik.

Bahan yang digunakan dalam penelitian ini adalah sebagai berikut : (1) Serat bundung. Serat dibelah menjadi ukuran $1 \mathrm{~mm}$, serat disusun dengan arah sudut serat gabungan $0^{\circ}$ dan $90^{\circ}$ sehingga tersusun secara teratur sebagai bahan serat. (2) Matrik yang digunakan jenis polyester type 157 BQTN, (3) Katalis MEKPO sebesar 1\% untuk proses curing (pengeringan), (4) $\mathrm{NaOH},(5)$ Aquades

Adapun peralatan yang digunakan dalam penelitian adalah sebagai berikut (1) Alat tekan cetak, (2) Cetakan tekan, (3) Timbangan digital (4). Alat pengering, (5) Grinding machine dan Amplas Belt, (6) Mesin uji tarik, (7) Alat bantu lain.

Variabel bebas yang digunakan adalah perbandingan fraksi volume serat masingmasing 20\%, 30\%, dan 40\%. Variabel terikat yaitu menggunakan uji tarik (ASTM D638-03). Variabel terkontrol yaitu :

- Pengujian spesimen tanpa perlakukan serat

- Pengujian spesimen dengan perlakukan serat dengan perendaman $5 \% \mathrm{NaOH}$ selama 2 jam

- Pengujian spesimen dengan perlakukan serat dengan perendaman $5 \% \mathrm{NaOH}$ selama 2 jam dengan pemanasan $70^{\circ} \mathrm{C}$ selama 4 jam

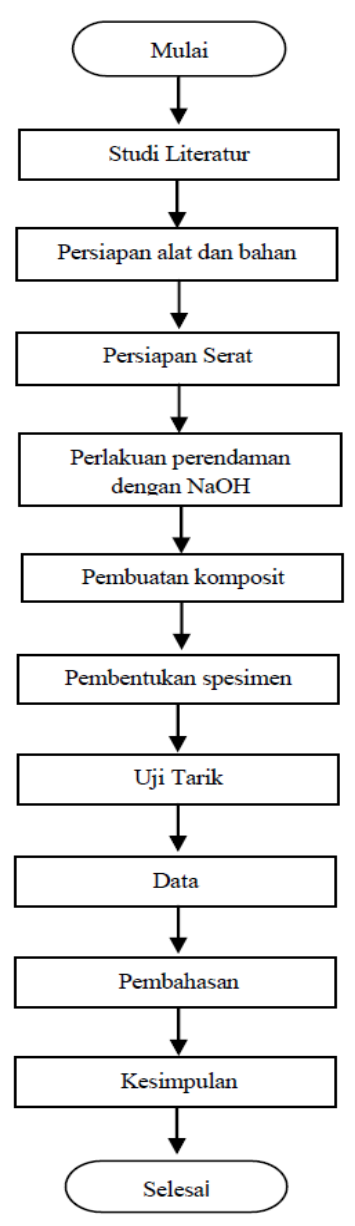

Gambar 1. Diagram alir penelitian

Diagram Alir Penelitian 
1. Tanaman bundung yang telah diambil, dibersihkan dan dikeringkan selama 7 hari.

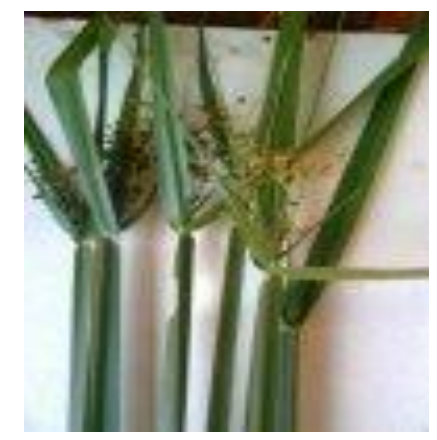

Gambar 2. Bundung segar

2. Setelah kering, serat bundung direndam lagi selama 24 jam dengan tujuan memudahkan menyerutan menggunakan sikat baja.

3. Setelah serat bundung diserut, kemudian dilakukan perlakuan perendaman dalam $5 \%$ $\mathrm{NaOH}$ selama 2 jam. Perendaman ini bertujuan untuk memodifikasi sifat permukaan secara kimiawi sehingga memperbaiki ikatan resin dan fiber, dimana perendaman dalam larutan $\mathrm{NaOH}$ akan mengurangi hemicelluloses dan lignin pada serat alam (Vallo, 2004). Kemudian cuci dengan air mengalir selama \pm 30 menit, dan dikeringkan pada alat pengering selama \pm 12 jam.

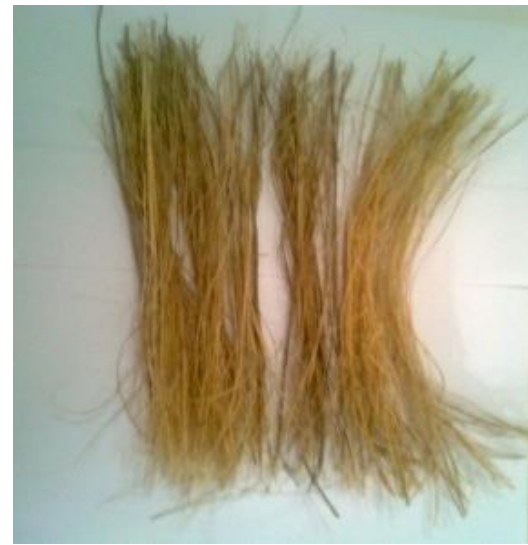

Gambar 3. Serat bundung

Pembuatan Komposit

Dalam pembuatan komposit digunakan serat bundung langkah-langkahnya adalah :

1. Resin dicampur dengan hardener dengan perbandingan 1\% hardener per berat resin polyester. Kemudian dilakukan pengadukan selama \pm 60 detik agar campuran resin dan hardener merata.
2. Kemudian campuran tersebut dituangkan secara merata sebagai lapisan pertama cetakan.

3. Lakukan pembersihan terhadap void hingga void berkurang dan tidak terdapat void yang secara visual diameternya tidak lebih dari 1 $\mathrm{mm}$.

4. Letakkan serat bundung dengan arah sudut gabungan $0^{\circ}$ dan $90^{\circ}$ diatasnya, sebagai lapisan ke dua. Tuang campuran polyesterhardener sampai cetakan penuh

5. Lakukan pembersihan void seperti langkah no. 4.

6. Keringkan komposit pada suhu kamar selama \pm 12 jam. Setelah benar-benar kering, keluarkan komposit dari cetakan.

7. Lakukan pengamatan pada komposit terhadap ada tidaknya void yang terjadi dengan cara menerawang lembaran komposit. Diameternya tidak lebih dari $1 \mathrm{~mm}$. Void tidak boleh mengumpul pada suatu tempat (radius jarak antar void yang diijinkan adalah $1 \mathrm{~cm}$ )

8. Bentuklah spesimen uji sesuai dengan standar uji tarik (ASTM D638-03)

9. Memanaskan komposit dalam oven dengan temperatur $70^{\circ} \mathrm{C}$ selama 4 jam

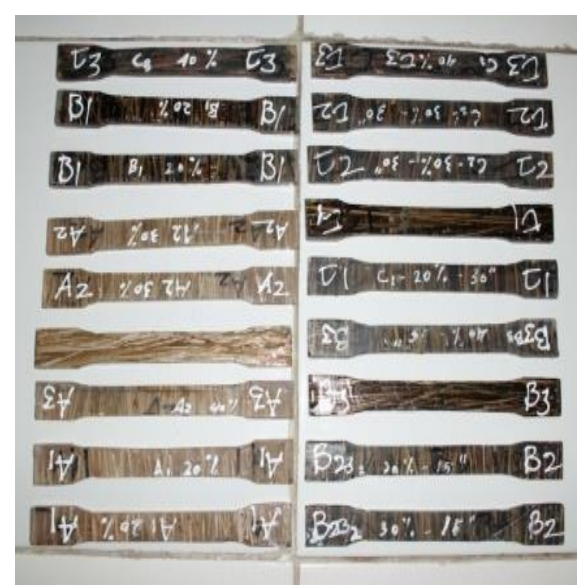

Gambar 4. Spesimen uji tarik 


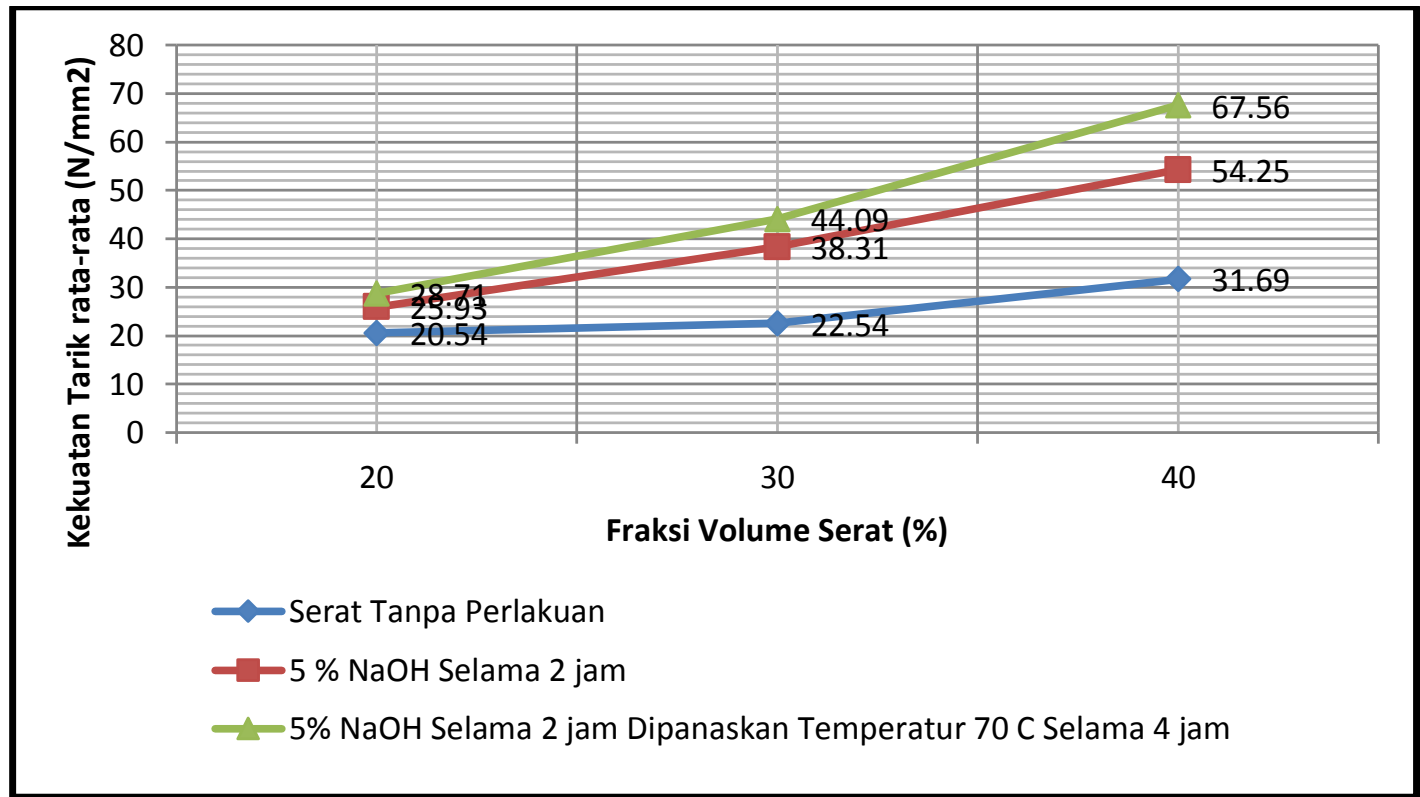

Gambar 5. Grafik kekuatan tarik serat bundung

Tabel 1. Kekuatan tarik rata-tara serat bundung dengan perlakuan dan tanpa perlakuan

\begin{tabular}{|c|c|c|c|c|}
\hline No & Material & $\begin{array}{c}\text { Max } \\
\text { Load } \\
(\mathrm{N})\end{array}$ & $\begin{array}{c}\text { Kekuatan } \\
\text { Tarik } \\
\left(\mathrm{N} / \mathrm{mm}^{2}\right)\end{array}$ & $\begin{array}{c}\text { Modulus } \\
\text { elastisitas } \\
(\mathrm{Gpa})\end{array}$ \\
\hline 1 & $20-$ Biru & 1620 & 20,54 & 45,63 \\
\hline 2 & $30-$ Biru & 1760 & 22,54 & 55,62 \\
\hline 3 & $40-$ Biru & 2472 & 31,69 & 79,80 \\
\hline 4 & $\begin{array}{c}20- \\
\text { Merah }\end{array}$ & 2023 & 25,93 & 69,77 \\
\hline 5 & $\begin{array}{c}30- \\
\text { Merah }\end{array}$ & 2989 & 38,31 & 82,42 \\
\hline 6 & $\begin{array}{c}40- \\
\text { Merah }\end{array}$ & 4231 & 54,25 & 146,76 \\
\hline 7 & $\begin{array}{c}20- \\
\text { Hijau }\end{array}$ & 2242 & 28,71 & 76,39 \\
\hline 8 & $\begin{array}{c}30- \\
\text { Hijau }\end{array}$ & 3439 & 44,09 & 98,74 \\
\hline 9 & $\begin{array}{c}40- \\
\text { Hijau }\end{array}$ & 5268 & 67,56 & 174,13 \\
\hline
\end{tabular}

Hasil pengujian tarik serat bundung tanpa perlakuan :

Dari hasil pengujian tarik didapatkan kekuatan tarik yang paling optimal yaitu pada fraksi volume $40 \%$ serat sebesar $31,69 \mathrm{~N} / \mathrm{mm}^{2}$, sedangkan yang terendah yaitu pada fraksi volume $20 \%$ serat sebesar $20,45 \mathrm{~N} / \mathrm{mm}^{2}$.

Hasil pengujian tarik serat bundung perlakuan perendaman $5 \% \mathrm{NaOH}$ selama 2 jam :

Dari hasil pengujian tarik didapatkan kekuatan tarik yang paling optimal yaitu pada fraksi volume $40 \%$ serat sebesar $54,25 \mathrm{~N} / \mathrm{mm}^{2}$, sedangkan kekuatan tarik yang terendah adalah komposit serat bundung dengan fraksi volume $20 \%$ serat sebesar $25,93 \mathrm{~N} / \mathrm{mm}^{2}$.

Hasil pengujian tarik serat bundung perlakuan perendaman $5 \% \mathrm{NaOH}$ selama 2 jam dengan pemanasan $70^{\circ} \mathrm{C}$ selama 4 jam :

Dari hasil pengujian ini didapatkan kekuatan tarik yang paling optimal pada fraksi volume $40 \%$ serat yaitu sebesar 67,56 N/ $\mathrm{mm}^{2}$, sedangkan yang terendah adalah komposit serat bundung dengan fraksi volume $20 \%$ serat yaitu sebesar $28,71 \mathrm{~N} / \mathrm{mm}^{2}$.

Pembahasan

Kekuatan ini dipengaruhi oleh penambahan volume serat yang dapat meningkatkan kekuatan tarik.

Komposit serat bundung yang diberi perlakuan 5\% NaOH selama 2 jam kekuatan tariknya lebih tinggi dibandingkan dengan komposit serat bundung tanpa perlakuan perendaman $\mathrm{NaOH}$. Dapat disimpulkan bahwa serat bundung tanpa perlakuan perendaman $\mathrm{NaOH}$ masih terdapat lignin dan hemicellulosa sehingga interface antara serat dan resin tidak terjadi ikatan yang baik, kegagalan tersebut didominasi oleh lepasnya ikatan serat dengan resin.

Komposit serat bundung yang diberi perlakuan perendaman serat $5 \% \mathrm{NaOH}$ selama 2 jam dan yang dipanaskan $70^{\circ} \mathrm{C}$ selama 4 jam kekuatan tariknya lebih tinggi dibandingkan dengan komposit serat bundung yang hanya diberi perlakuan perendaman serat $5 \% \mathrm{NaOH}$ selama 2 jam saja. Dapat disimpulkan bahwa serat bundung yang diberi perlakuan tambahan 
pemanasan komposit $70^{\circ} \mathrm{C}$ selama 4 jam kekuatan tariknya akan semakin besar dikarenakan void-void yang terdapat di dalam komposit telah hilang sehingga ikatan antara serat dan resin akan semakin lebih baik. Dengan hilangnya void-void yang terdapat di dalam komposit maka beban tarik yang diberikan pada komposit akan terdistribusi pada serat dengan baik, dan sebaliknya apabila interface antara serat dan resin tidak hilang maka beban tarik hanya ditahan oleh resin saja, sedangkan volume resin sudah berkurang akibat penambahan serat. Dengan kata lain kekuatan komposit hanya terletak pada resin saja.

\section{Kesimpulan}

Berdasarkan hasil pengujian yang telah dilakukan maka dapat disimpulkan bahwa upaya peningkatan kualitas sifat mekanik komposit dengan arah sudut serat gabungan $0^{\circ}$ dan $90^{\circ}$ pada polyester dengan perlakuan perendaman $5 \% \mathrm{NaOH}$ selama 2 jam dan dengan pemanasan $70^{\circ} \mathrm{C}$ selama 4 jam dapat meningkatkan kekuatan mekanik komposit. Dimana dari hasil pengujian dapat dilihat bahwa lapisan lignin dan hemicellulosa akan hilang dari serat bundung dengan cara perlakuan perendaman dengan $\mathrm{NaOH}$ dan juga void dapat hilang dengan cara komposit dipanaskan dengan temperatur $70^{\circ} \mathrm{C}$.

\section{Daftar Pustaka}

1. Ashby, M.F, Jones, D.R.H. 1986 . Engineering Material 2 An Introduction to Microstutures Processing and Design, $1^{\text {st }}$ Edition

2. Bilmeyer, F., 1984, Text Book of Polymer Science, New York, Shonwiley \& Sons

3. Budinski K.G. 1995. Engineering Material Properties and Selection, $4^{\text {th }}$, Prentice Hall, Inc A Simon and Schuster Company,USA.

4. Delni Sriwita, 2014. Pembuatan dan karateristik mekanik bahan komposit serat daun nenas polyester ditinjau dari fraksi massa dan orientasi serat. Jurnal Fisika Unand vol 3.

5. Hairu Abral . 2010 . Studi kekuatan tarik sifat fisi serat cyathea contaminans sebelum dan setelah mengalami perlakuan Alkali. Jurnal Teknik Mesin 